August 2002 - NREL/TP-550-30270

\title{
Building America System Performance Test Practices: Part 2, Air-Exchange Measurements
}

Ed Hancock

Mountain Energy Partnership

Paul Norton and Bob Hendron

National Renewable Energy Laboratory

Center for Buildings and Thermal Systems

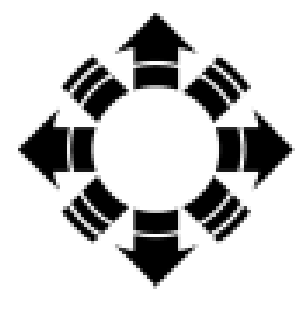

\section{NPEI}

National Renewable Energy Laboratory

1617 Cole Boulevard

Golden, Colorado 80401-3393

NREL is a U.S. Department of Energy Laboratory

Operated by Midwest Research Institute $\bullet$ Battelle $\bullet$ Bechtel

Contract No. DE-AC36-99-G010337 


\section{Building America System Performance Test Practices: Part 2, Air-Exchange Measurements}

Ed Hancock

Mountain Energy Partnership

Paul Norton and Bob Hendron

National Renewable Energy Laboratory

Center for Buildings and Thermal Systems

Prepared under Task No. BET1.8004

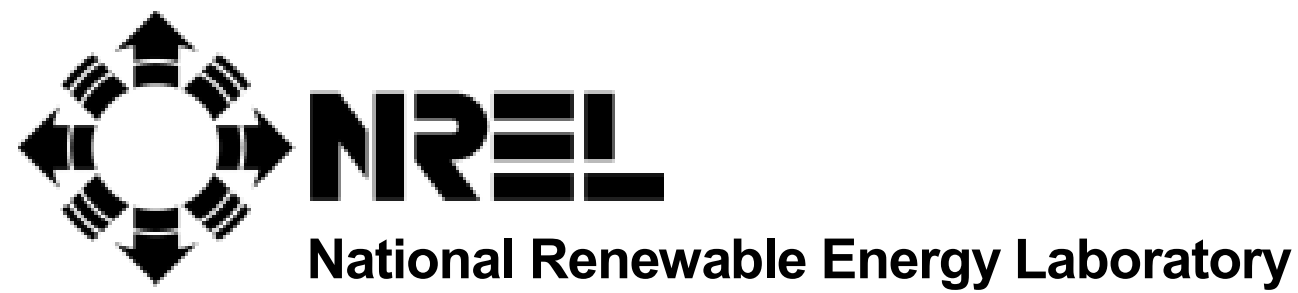

1617 Cole Boulevard

Golden, Colorado 80401-3393

NREL is a U.S. Department of Energy Laboratory

Operated by Midwest Research Institute • Battelle • Bechtel

Contract No. DE-AC36-99-G010337 


\section{NOTICE}

This report was prepared as an account of work sponsored by an agency of the United States government. Neither the United States government nor any agency thereof, nor any of their employees, makes any warranty, express or implied, or assumes any legal liability or responsibility for the accuracy, completeness, or usefulness of any information, apparatus, product, or process disclosed, or represents that its use would not infringe privately owned rights. Reference herein to any specific commercial product, process, or service by trade name, trademark, manufacturer, or otherwise does not necessarily constitute or imply its endorsement, recommendation, or favoring by the United States government or any agency thereof. The views and opinions of authors expressed herein do not necessarily state or reflect those of the United States government or any agency thereof.

Available electronically at http://www.osti.gov/bridge

Available for a processing fee to U.S. Department of Energy

and its contractors, in paper, from:

U.S. Department of Energy

Office of Scientific and Technical Information

P.O. Box 62

Oak Ridge, TN 37831-0062

phone: 865.576.8401

fax: 865.576.5728

email: reports@adonis.osti.gov

Available for sale to the public, in paper, from:

U.S. Department of Commerce

National Technical Information Service

5285 Port Royal Road

Springfield, VA 22161

phone: 800.553.6847

fax: 703.605.6900

email: orders@ntis.fedworld.gov

online ordering: http://www.ntis.gov/ordering.htm 


\section{TABLE OF CONTENTS}

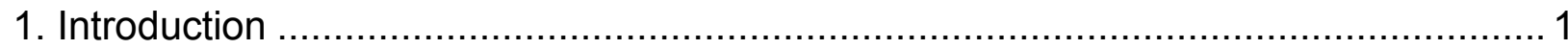

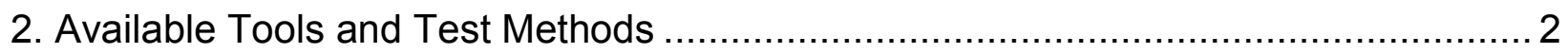

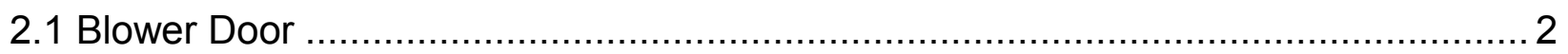

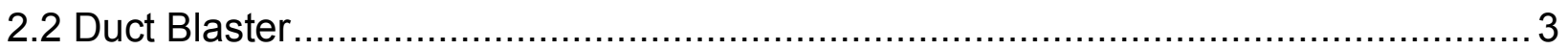

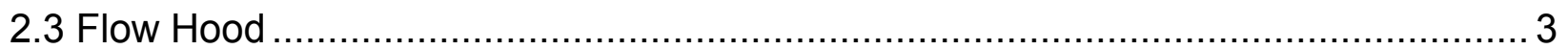

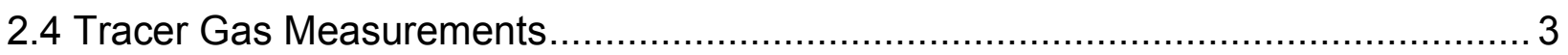

3. Calculating Energy Use Due To Infiltration and Ventilation ................................... 5

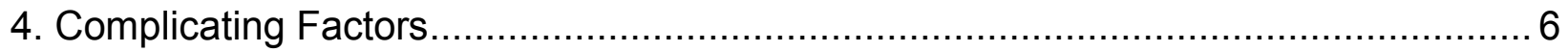

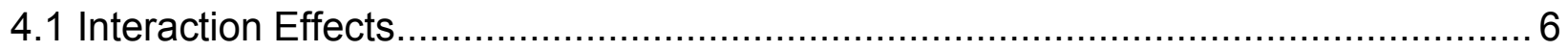

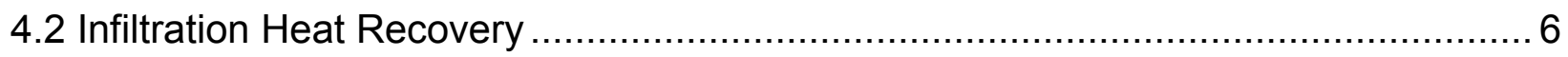

5. Example of Air-Exchange Measurement: Medallion Homes, San Antonio, August

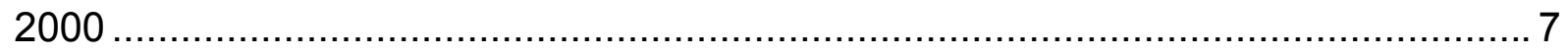

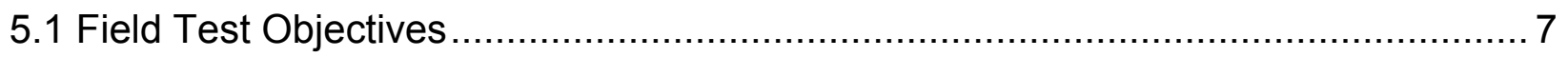

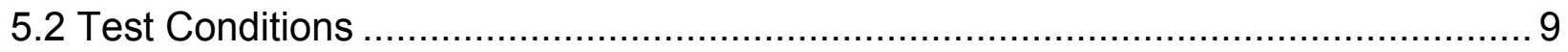

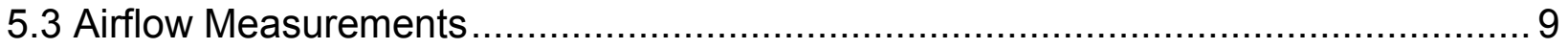

5.4 Blower door and Duct Blaster Measurements ................................................. 11

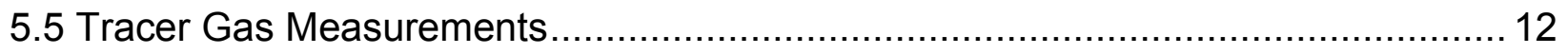

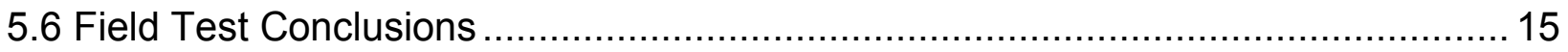

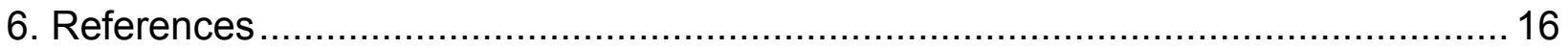




\section{List of Figures}

Figure 1. Example decay of $\mathrm{SF}_{6}$ concentration in a test home ..........................4

Figure 2. Measured air-exchange rates for prototypes and standard practice houses. (Zero is midnight; day of week label is noon.)

The figure includes the results for a two-story home not discussed in this report.

Figure 3. Measured wind speed during the tracer gas measurement period......14

Figure 4. Average air temperatures during the tracer gas measurement period

\section{List of Tables}

Table 1. Medallion Homes Test House Descriptions (Expected) .......................8

Table 2. Supply Airflow Summary .........................................................10

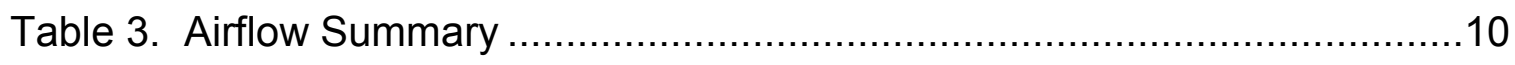

Table 4. Blower Door and Duct Blaster Measurements..................................11 


\section{Acknowledgments}

Many thanks to Ren Anderson and Sara Farrar-Nagy of NREL for their long-time commitment to quality technical research in the Building America Program; to Greg Barker of Mountain Energy Partnership, Paul Reeves of the Partnership for Resource Conservation, and Dennis Barley and Ron Judkoff of NREL for their thoughtful reviews and comments; and to Bill Cobban, Lauren Poole, and Nancy Wells of NREL for their technical editing and document preparation work support.

We thank the staff of Integrated Building and Construction Solutions (IBACOS) Consortium of the Building America Program who partnered with NREL on the field-test example contained in this report. We also express our gratitude to George James, Department of Energy Program Manager for Building America, for the leadership and resources needed to complete this work. 


\section{Introduction}

This document outlines the current test practices used by NREL staff and contractors to quantify the air-exchange characteristics of homes built within the Building America Program. It is not intended to be a standard protocol for these measurements. Instead, it documents the test methods currently being used to increase understanding of their advantages and limitations and to promote discussion of the approach used.

The Building America Program is an industry-driven program sponsored by the U.S. Department of Energy (DOE) that uses systems engineering approaches to accelerate the development and adoption of advanced building energy technologies in production housing. Building America partners with residential building industry teams to produce advanced residential buildings on a community scale. The Building America Teams work directly with production builders to develop methods to increase the quality and reduce the energy consumption of the homes that they build. Residential building systems are evaluated by conducting successive design, build, test, redesign, build, and retest iterations until cost and performance trade-offs yield innovations that can be implemented in production-scale housing. Building

The Building America program is responsible for evaluating features of new construction that affect the energy efficiency and quality of the home. One of the specific tasks in this effort is to quantify the envelope and air-distribution-system airtightness. Substantial energy savings may be available if current practice does not already produce tight houses. On the other hand, a minimum amount of outside air is required for acceptable indoor air quality, so continuing to expend efforts on further tightening when standard practice already achieves tight houses may not be beneficial. The amount of air exchange that actually occurs is not apparent to homebuilders or owners. This places an emphasis on testing to evaluate the success of airinfiltration reduction strategies.

It is important to initially test the airtightness of the builder's current standard practice to evaluate the need for envelope improvements and ventilation requirements. Many houses built using current standard practice result in air-exchange rates that are already low compared to minimum requirements. These houses may need mechanical ventilation for indoor air quality and may not benefit from additional efforts to improve airtightness, unless heat recovery ventilation (HRV) is used. Testing the current standard practice can indicate whether or not infiltration should even be included for consideration in the Building America energy efficiency package for a given builder. The relative importance of envelope leakage and duct leakage must also be evaluated to understand the effects of operating the distribution fan on the overall performance of the house.

The following is a basic question for evaluating Building America prototype houses:

What are the air exchange characteristics of the envelope and ducts of Building America homes?

The general approach in addressing this question is to characterize the shell leakage, duct leakage, and intentional ventilation for both the prototype and base case. These characteristics 
are compared to leakage goals set by the builder and specified in standards such as ASHRAE 62.2P: Ventilation and Acceptable Indoor Air Quality in Low-Rise Residential Buildings.

Several specific questions are usually important in our evaluation of airtightness in Building America houses, including the following:

- How does the airtightness characteristic (effective leakage area, ELA) of the envelope in the Building America prototype compare to the builder's standard practice?

- How does the natural infiltration rate (air changes per hour, $\mathrm{ACH}$ ) in the Building America prototype compare to the builder's standard practice?

- How does the duct system airtightness characteristic of the Building America prototype compare to the builder's standard practice?

- How does the duct air leakage during normal operation of the air handler in the Building America prototype compare to the builder's standard practice?

- Does operation of the air handler cause additional air leakage through the shell of the building?

- Is the performance of the ventilation system adequate to supply the minimum required ventilation in all seasons?

- Is the air handler distributing air appropriately to all parts of the house?

\section{Available Tools and Test Methods}

\subsection{Blower Door}

A blower door is a device used to pressurize or depressurize a house to determine the leakage characteristics of the building envelope. A variable-speed fan is temporarily mounted in a doorway or other opening to pressurize (or depressurize) the house by specified amounts. The flow rate through a calibrated orifice is measured at the different house pressures. The relationship between flow rate and pressure difference is an indication of shell airtightness. Weatherization contractors often use blower door testing, and some builders and mechanical contractors also have equipment in-house for doing blower door tests. For full details on blower door operating procedures, see reference [1]. The blower door method is also documented in standards ASTM E779 [2], ASTM E1827 [3], ANSI/ASHRAE 136 [4], and ANSI/ASHRAE 119 [5].

The results of the blower door tests can be expressed as one of several figures of merit. One simple expression of the envelope tightness is the blower door flow rate at a pressure difference of 50 Pascals $(\mathrm{Pa})$ or "CFM50." This test is the simplest and easiest to perform because it requires the blower door operator to determine only one pressure (50 Pa) and one flow rate. The 50-Pa pressure is the highest used in a typical blower door test and is the least sensitive to the influence of wind variation during the test. It, therefore, tends to be more repeatable than parameters that require measurements at lower pressures, but does not provide adequate information to use in algorithms for calculating actual air-exchange rates [6]. ACH50 is the air changes per hour at $50 \mathrm{~Pa}$ (equal to the CFM50 multiplied by 60 minutes per hour and divided by the house volume). ACH50 can be a useful metric for comparing houses of different sizes.

The Equivalent Leakage Area (ELA) is defined as the area of a calibrated orifice that would have the same air flow rate the house does at a pressure of $4 \mathrm{~Pa}$. The ELA, therefore, is an estimate of 
the aggregate size of all the leaks in the building. An ELA can be calculated from the results of a multipoint blower door test. NREL uses a laptop computer with TECTITE software [7] to automatically control the blower door during multipoint tests. We usually take 100 data points at each of 8 different pressures between 15 and $50 \mathrm{~Pa}$ to determine the relationship between pressure and leakage rate for the test home. The ELA is based on the leakage rate at a 4-Pa pressure difference, which is determined by a curve fit to the blower door test data at various pressures. The ELA can then be used in conjunction with weather conditions at the home site to model the natural $\mathrm{ACH}$ at particular times and to estimate long-term or annual infiltration rates $[1,6,8]$.

\subsection{Duct Blaster}

A Duct Blaster, a device similar to a blower door, is used to pressurize only the air-distribution system, including the ducts and air handler cabinet. During the test, all supply and return registers are taped closed, and the duct blaster fan is temporarily mounted to pressurize the taped-off duct system. A multipoint test could be performed to infer a leakage area, but it is more common to pressurize to a reference pressure of $25 \mathrm{~Pa}$. NREL typically performs a single point test at $25 \mathrm{~Pa}$. The flow rate at this pressure is an indication of the leakage characteristic of the air-distribution system. The supply and return sections of the air-distribution system can be separately tested by inserting a blocking section in the air handler. An inference can be made as to the proportion of leakage to the outside under test conditions by pressurizing the house to reference pressure using a blower door during the duct blaster test. Because the ducts and house are then at the same pressure, any leakage from the ducts is assumed to be to the outside rather than to the house. The results of this test provide a useful benchmark for evaluating the general quality of the air-distribution system, but the test results do not directly indicate duct air leakage during normal operation of the system. For full details on duct blaster operating procedures, see reference [9] and ASTM E1554 [10]. NREL has also begun experimenting with the Nulling Test, proposed by Francisco and Palmiter [11] for estimating duct leakage.

\subsection{Flow Hood}

A flow hood is a device that measures the airflow rate into or out of a register while the air handler is operating. The flow hood channels the air through a short fabric duct containing thermal anemometers to measure the flow of air entering or exiting the register. The NREL field test team uses an Alnor Low-Flow Balometer with a range of 10 to 500 cubic feet per minute (cfm) and a rated accuracy of $\pm 3 \%$ of reading $+2 \mathrm{cfm}$. During normal air handler operation, the flow hood is held over each supply and return register and the flow rate for that register is recorded. These measurements are used to check the total air flow for the house and room-toroom air flow balance.

\subsection{Tracer Gas Measurements}

Blower door and duct blaster tests provide measurements of the leakage characteristics of the envelope and air-distribution systems, but may not be accurate for predicting how much outside air actually enters a particular house under particular driving forces. Tracer gas measurements can provide such direct measurements. The test method typically used for Building America evaluation is the tracer decay using sulfur hexafluoride $\left(\mathrm{SF}_{6}\right)$ as the tracer gas. In this test, a small amount of $\mathrm{SF}_{6}$ is initially injected into the house and mixed to achieve a uniform concentration. As infiltration or intentional ventilation brings outside air into the house, the concentration of $\mathrm{SF}_{6}$ is diluted. The rate of change (decay) of $\mathrm{SF}_{6}$ concentration indicates the air-exchange rate of the house expressed as air changes per unit time. This method is documented in ASTM E741 [12]. An example of this decay rate is shown in Figure 1. 


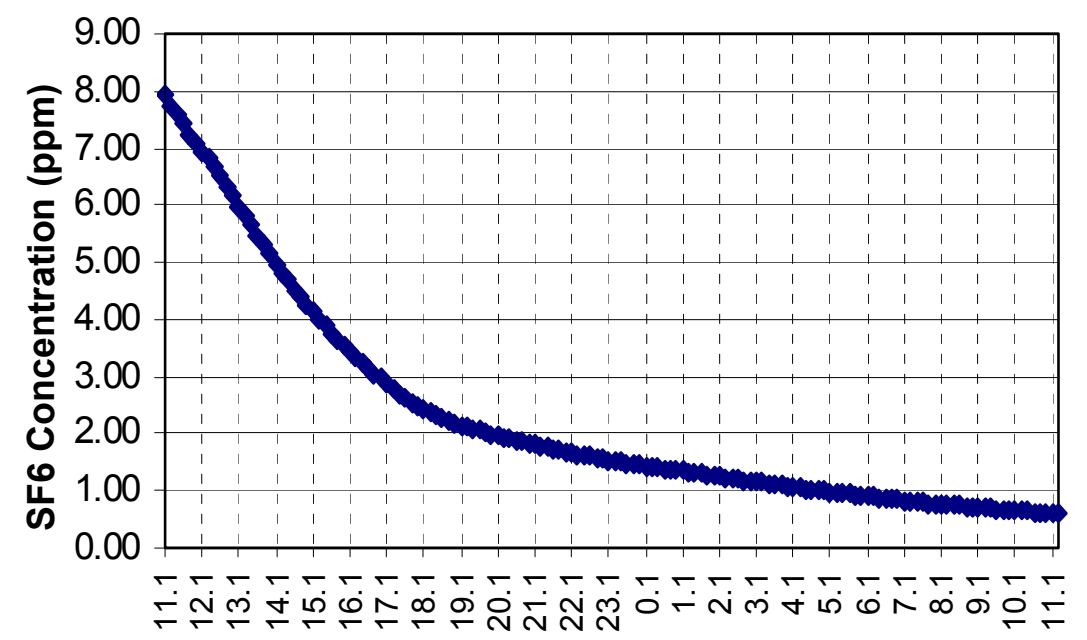

Hour

\section{Figure 1. Example decay of $\mathrm{SF}_{6}$ concentration in a test home}

The air-exchange rate measured with tracer gas can be compared to that calculated using blower door measurements. Many studies have indicated that, in general, this comparison can show large differences between the two methods $[13,14,18]$. The tracer gas test results can be used to improve the choice of difficult-to-know inputs for the blower-door model and produce an improved comparison between tracer gas measurement and blower door model estimation.

Duct blaster tests are intended to quantify the duct leakage under standard conditions, they do not capture the nuances of actual operating conditions. Because we are interested in duct leakage due to air handler operation under actual operating conditions, we use tracer gas tests. In this test, an $\mathrm{SF}_{6}$ decay test is initiated with the air handler turned off and the inside temperature maintained with electric heaters without use of the normal heating system. During this period, the natural infiltration of the building envelope is measured without any influence of duct leakage. The air handler is then turned on to operate continuously for several hours. The step-change in airexchange rate at the time of turning on the air handler is attributed to duct leakage. A similar indication can be observed in the step-change in air-exchange rate when the air handler is turned off. 


\section{Calculating Energy Use Due To Infiltration and Ventilation}

In most cases, we measure the infiltration and ventilation characteristics to compare them with standards and the builder's goals. Our objective, therefore, is to accurately measure the air exchange characteristics of the homes and report them back to the builder through the Building America teams. This is the case for the example given later in this report.

On occasion we have also evaluated the energy use due to air exchange in prototype and basecase homes. The net air-exchange rate of the house results from the combined effects of infiltration, duct leakage, and intentional ventilation. The combined effect of these flow rates is specified as an input to an hourly energy simulation model (such as DOE2), which is used to calculate the annual heating and cooling energy required to maintain the temperature and humidity conditions for the building. We can then compare this rate of energy use to the energy use in a base-case home with different air-exchange characteristics to determine the energy impacts of the air-exchange characteristics.

When the house is not equipped with a mechanical ventilation system, we use the ELA from a blower door test and have the model calculate envelope infiltration using the Lawrence Berkeley Laboratory (LBL) model [15]. This is superimposed with the induced ventilation due to duct leakage to calculate the net air-exchange rate.

For houses with mechanical ventilation systems, several weeks of tracer gas testing data are collected on the net air-exchange rate of the house with air handler on and off, with ventilation system on and off and under various temperature and wind conditions. A linear regression model is then used to relate the measured air-exchange rate to the monitored air-infiltration drivers of: central heating/cooling mechanical system operation, separate ventilation system operation, wind speed and temperature difference between indoor and outdoor. The coefficients associated with the wind speed and temperature difference are used in an annual model for natural infiltration, while the coefficients of the system operation drivers are used to characterize the performance of those systems. 


\section{Complicating Factors}

Some factors that influence actual air exchange and resulting heat exchange are difficult to characterize in one-time tests and can result in significant uncertainty in evaluating energy savings from airtightening.

\subsection{Interaction Effects}

The airflows caused by infiltration, duct leakage, and intentional ventilation are not independent. Duct leakage and intentional ventilation can change the pressure distribution within the building, which in turn, changes the infiltration rate due to wind and stack effect. A ventilation fan flow rate of $50 \mathrm{cfm}$ may not result in a $50 \mathrm{cfm}$ net change of the building air-exchange rate because the ventilation fan also changes the pressure distribution that causes infiltration. The interaction of these effects is a potential future research project for the Building America Program

\subsection{Infiltration Heat Recovery}

The infiltration heat recovery factor has been described and measured by several investigators $[16,17,18]$. In this phenomenon, air that flows through the materials of the building envelope exchanges heat with the building materials as it passes between inside and outside. A portion of the heat loss that would be attributed to air infiltration is thus "recovered," and heating or cooling loads are reduced accordingly. The magnitude of the infiltration heat recovery effect is difficult to predict in advance or measure in place for a particular building and has been reported to range from near zero to more than 50 percent with most studies averaging about 20 percent. For the purposes of evaluation with simulations, we currently assume that no infiltration heat recovery takes place. If it does occur to about the same extent in the prototype and base-case houses, the actual energy use (and savings) would be reduced. We are not aware that any Building America measures actually attempt to enhance the infiltration heat-recovery effect.

The air-exchange rates estimated in our analyses for evaluating energy savings assume that natural driving forces and mechanical system operation determine air exchange. In occupied houses, the behavior of the occupants can have a significant influence on actual air-exchange rates and energy savings. Occupants exercise a wide range of behaviors with respect to opening and closing windows and exterior and interior doors. In some cases, the operation of the ventilation system is at the discretion of the occupants. In building energy simulations, we make reasonable assumptions for opening and closing of windows and operation of ventilation equipment [19]. 


\section{Example of Air-Exchange Measurement: Medallion Homes,}

\section{San Antonio, August 2000}

This section contains the description and results of a field test of the air-exchange characteristics of two homes in San Antonio, Texas. During the field-testing, we also measured the energy consumption of the homes. However, only the air-exchange tests are described here. This is given as an example of the test practices outlined earlier. In this example, no energy simulation was performed. The results and discussion of the air-exchange tests were supplied to Integrated Building and Construction Solutions (IBACOS), the Building America Team involved in the project. This information was used in their work with Medallion Homes to improve the energy efficiency of Medallion's building practices.

\subsection{Field Test Objectives}

The objective of these short-term tests was to evaluate and compare the air-exchange characteristics of a Medallion Homes pilot house and a base-case house, both of which were onestory homes in San Antonio, Texas. The pilot house was originally tested in January 2000 and was located in the Mainland Square residential development. The base-case house had a similar floor plan as the pilot home and was located at the Finesilver Ranch community. The tests were conducted during the cooling season, which is the dominant season in San Antonio. The primary differences between the two houses were fan-controlled return air ventilation versus no controlled ventilation, air handler and supply ducts in conditioned space versus in the attic, and high interior wall supply registers versus perimeter ceiling supply registers. Specifications for the prototype and base-case houses are summarized in Table 1.

A combination of tests incorporating blower door, duct blaster, flow hood, and tracer gas was conducted to answer the following questions:

1. What is the natural infiltration rate $(\mathrm{ACH})$ of each house as measured by a tracer gas under the following conditions?

a. Air handler unit (AHU) and ventilation system inlets blocked (envelope only)

b. With AHU operating, but ventilation system inlets blocked (ducts and envelope)

c. Normal operation of AHU and ventilation system (ventilation system effectiveness)

2. What are the blower door results (ACH50, CFM50, ELA, and estimated natural $\mathrm{ACH})$ for each house?

3. What is the duct leakage (CFM50) for each house (supply to inside, supply to outside, return to inside, and return to outside)?

4. What the register flow rate at each supply register? 
Table 1. Medallion Homes Test House Descriptions (Expected)

\begin{tabular}{|c|c|c|}
\hline & Pilot Home & One-Story Base Case \\
\hline Location & $\begin{array}{l}\text { Mainland Square Subd. } \\
8646 \text { Sunny Oaks } \\
\text { San Antonio, TX } 78250\end{array}$ & $\begin{array}{l}\text { Finesilver Ranch Subd. } \\
\text { Lot \#2 } \\
\text { Ferris Branch Road } \\
\text { San Antonio, TX }\end{array}$ \\
\hline Model & $\begin{array}{l}\text { Haskellas Model } 1537 \\
\text { 1-story, slab-on-grade } \\
3 \text { bedrooms }\end{array}$ & $\begin{array}{l}\text { Augusta Model } \\
1 \text {-story, slab-on-grade } \\
4 \text { bedrooms }\end{array}$ \\
\hline Size (sq. ft.) & 1,537 & 1,752 \\
\hline $\begin{array}{l}\text { Front } \\
\text { orientation }\end{array}$ & North & West \\
\hline Garage & Detached & Attached \\
\hline Insul: - Walls & $\begin{array}{l}\text { R-13 blown-in cellulose, } \\
2 \times 4 \text { framing, building } \\
\text { paper }\end{array}$ & Same \\
\hline - Roof & $\begin{array}{l}\mathrm{R}-38 \text { loose-fill fiberglass, } \\
\text { truss framing, vented }\end{array}$ & Same \\
\hline- Slab & None & Same \\
\hline Windows & $\begin{array}{l}\text { Double-pane, low-e } \\
\text { spectrally selective } \\
\text { coating, vinyl frame }\end{array}$ & Same \\
\hline Shading & $\begin{array}{l}\mathrm{U}=0.24 \text {, } \mathrm{SHGC}=0.41 \\
\text { No shading on south, east, } \\
\text { or west sides }\end{array}$ & $\begin{array}{l}\text { Moderate shading on } \\
\text { south and east sides; no } \\
\text { shading on west }\end{array}$ \\
\hline Ventilation & $\begin{array}{l}\text { Outside air duct with fan } \\
\text { to return of air handler, } \\
\text { backdraft damper \& } \\
\text { AirCycler control ( } 10 \\
\text { min. on, } 15 \text { min. off), } \\
\text { design airflow rate } 120 \\
\text { cfm }\end{array}$ & $\begin{array}{l}\text { Continuous exhaust } \\
\text { ventilation in laundry } \\
\text { room }\end{array}$ \\
\hline \multirow[t]{3}{*}{ Ducts } & $\begin{array}{l}\text { Air handler in interior } \\
\text { closet }\end{array}$ & Air handler in attic \\
\hline & $\begin{array}{l}\text { Supply ducts in dropped } \\
\text { ceiling within conditioned } \\
\text { space, } 2 \text { return ducts in } \\
\text { attic }\end{array}$ & $\begin{array}{l}\text { Supply \& return ducts in } \\
\text { attic, } 2 \text { returns }\end{array}$ \\
\hline & $\begin{array}{l}\text { High interior wall supply } \\
\text { registers }\end{array}$ & $\begin{array}{l}\text { Ceiling perimeter supply } \\
\text { registers }\end{array}$ \\
\hline Heating & $\begin{array}{l}\text { Gas furnace in interior } \\
\text { closet with combustion air } \\
\text { duct, } 80 \% \text { AFUE, } 40 \\
\text { kBtuh }\end{array}$ & $\begin{array}{l}\text { Gas furnace in attic, } 80 \% \\
\text { AFUE, } 40 \mathrm{kBtuh}\end{array}$ \\
\hline Cooling & 12-SEER, 2 tons & 12-SEER, 2 tons \\
\hline Water Heating & 50 gallons, 40 kBtuh, & $\begin{array}{l}40 \text { gallons, power vented, } \\
0.62 \mathrm{EF}\end{array}$ \\
\hline
\end{tabular}




\subsection{Test Conditions}

Some of the house specifications deviated from what was expected. Ceiling insulation in all houses was sprayed-in cellulose instead of loose-fill fiberglass. The insulation depth was mostly 5 to 7 in. in the pilot home, which was consistent with an R-value in the range of 20-26 instead of R-38 as expected. A certificate from the installing company stated that the intended R-value was R-30 for the pilot home. There was a radiant barrier on the underside of the roof deck in the pilot home. The ventilation fan in the pilot home did not operate whenever the air handler operated, which was the case during the January 2000 test. The AirCycler controller counted down from 15 minutes even when the air handler was running, but the ventilation fan did not turn on unless the air handler was off. In the base case, the air conditioner capacity was 3 tons, not 2 tons as expected.

The weather conditions for the test period were severely hot and humid. The outside temperature ranged from $90-111^{\circ} \mathrm{F}$ during the daytime and $72-86^{\circ} \mathrm{F}$ at night. The winds were mild during the day and very still at night, relative humidity was high, and daytime skies were fairly clear every day. Thermostats were set for $75^{\circ} \mathrm{F}$ during all testing. However, the base-case house had been allowed to soak at a significantly higher temperature for an extended period before the test. As a result, there may have been some residual heat stored in the thermal mass for the first 1-2 days of the test. The air conditioners were turned off during the airflow and blower door measurements and for about 8 hours before the return from set-up test.

\subsection{Airflow Measurements}

Flow hood measurements were performed using an Alnor Low-Flow Balometer on each register with the air handler operating. These measurements are summarized in Tables 2 and 3 . The results indicated that with the exception of low flow to the master bathroom in the pilot house, supply air was distributed in reasonable quantities through each register. The low flow rate in the master bedroom was likely caused by obstructions or kinks in the corresponding air duct. The total supply flow rate for each model tracked the air conditioner capacity fairly well. As shown in Table 3, all exhaust fans in the bathrooms were functional. The laundry room exhaust fan was designed to serve as a source of continuous ventilation for the base case. However, this fan did not exhaust a sufficient amount of air to draw significant amounts of outside air into the house. Because of this issue, the exhaust fan in the master bathroom was used as the alternate ventilation system during the tracer gas testing of the base case. 
Table 2. Supply Airflow Summary

\begin{tabular}{lclc}
\hline $\begin{array}{c}\text { Pilot Home } \\
\text { One-story) }\end{array}$ & $\begin{array}{c}\text { Supply Flow Rate, } \\
\left(\text { scfm*) }^{*}\right.\end{array}$ & $\begin{array}{c}\text { Base Case } \\
\text { (One-story) }\end{array}$ & $\begin{array}{c}\text { Supply Flow Rate, } \\
\text { (scfm) }\end{array}$ \\
\hline Kitchen 1 & 108 & Laundry & 86 \\
Kitchen 2 & 117 & Kitchen 1 & 48 \\
Living 1 & 128 & Kitchen 2 & 125 \\
Living 2 & 155 & Living 1 & 90 \\
NBR & 155 & Living 2 & 116 \\
WBR & 64 & Dining & 175 \\
Bath & 58 & Bath & 66 \\
Laundry & 32 & WBR & 60 \\
MBR & 112 & NBR & 63 \\
Mbath & 8 & MBR 1 & 92 \\
Mcloset & 38 & MBR 2 & 87 \\
& & MBath & 118 \\
& & MToilet & 22 \\
Total Supply scfm & & MCloset & 72 \\
\hline N Stand & Total Supply scfm & 1,220 \\
\hline
\end{tabular}

* Standard cubic feet per minute.

Table 3. Airflow Summary

\begin{tabular}{lcc}
\hline & $\begin{array}{c}\text { One-Story } \\
\text { Pilot Home }\end{array}$ & $\begin{array}{c}\text { One-Story } \\
\text { Base Case }\end{array}$ \\
\hline Total Supply cfm & 975 & 1,220 \\
Exhaust cfm & & \\
$\quad$ Bath & 24 & 25 \\
$\quad$ Mbath & 33 & \\
$\quad$ Mtoilet & & 34 \\
$\quad$ Laundry & 28 & 0 \\
2 Bath & & \\
Nominal tons & 2 & 3 \\
CFM per ton & 488 & 407 \\
\hline
\end{tabular}




\subsection{Blower Door and Duct Blaster Measurements}

Blower door measurements were conducted in accordance with ASTM Standard Test Method E779 [2]. The results are summarized in Table 4. Blower door data for the pilot home are based on earlier tests conducted by IBACOS on January 5, 2000. The combustion air duct in the mechanical room of the pilot home was taped closed during the blower door test, and the results represent the average of two separate tests. Using the Minneapolis Blower Door software developed by the Energy Conservatory, the ELA was calculated to be approximately 48 in. $^{2}$ for the pilot home. This is a relatively tight house, but not significantly tighter than the base-case houses when exterior surface area is factored in. Natural air-exchange rates for the test houses were estimated using a blower door program developed by Ron Judkoff, which is based on the Sherman-Grimsrud infiltration model, and actual weather conditions during the test period.

Minneapolis duct blaster testing was performed on the base-case house. Again, duct blaster measurements conducted by IBACOS in January 2000 were used for the pilot home in lieu of repeating the test. The results indicate that both total air leakage ( $7 \%$ of total flow) and leakage to the outside ( $1 \%$ of total flow) were smaller for the prototype than for the standard practice house (10\% and 5\% of total flow). By locating the air handler in a conditioned mechanical room and the supply ducts in a dropped ceiling, it appears that the builder significantly reduced the loss of conditioned air to the outside.

Table 4. Blower Door and Duct Blaster Measurements

\begin{tabular}{lrc}
\hline & $\begin{array}{c}\text { One-Story } \\
\text { Pilot Home }\end{array}$ & $\begin{array}{c}\text { One-Story } \\
\text { Base Case }\end{array}$ \\
\hline Blower Door & & \\
CFM50 & 1,004 & 1,212 \\
ELA @ 4 Pa, in. ${ }^{2}$ & 48 & 60 \\
ELA/100 ft $^{2}$ & 1.53 & 1.84 \\
surface area & & \\
C & 64.0 & 80.9 \\
N & 0.704 & 0.692 \\
$r^{2}$ & 0.9999 & 0.999 \\
ACH ${ }_{\text {nat }}$ & 0.10 & 0.11 \\
Duct Blaster & & \\
CFM at 25 Pa & & 118 \\
Total & 70 & 64 \\
$\quad$ to outside & 10 & 71 \\
Supply & 45 & 44 \\
to outside & 0 & 47 \\
Return & 10 & 20 \\
to outside & & \\
\hline Duct blaster results in italics indicate calculated values.
\end{tabular}




\subsection{Tracer Gas Measurements}

Bruel and Kjer 1302/1303 tracer gas-monitoring systems were installed in the pilot and base-case homes on Monday, August 28, 2000. Tubing was run to six sample points throughout each house, including one point without an extension tube. Sulfur Hexafluoride $\left(\mathrm{SF}_{6}\right)$ was periodically injected in all areas of each house and mixed to a uniform concentration using the air handlers. The air-exchange rate, stated as $\mathrm{ACH}$, was calculated based on the measured rate of decay in the concentration of $\mathrm{SF}_{6}$. Uniform concentration was not necessarily maintained during the decay period because the air handlers periodically cycled off under their own control programs. It is assumed that the average $\mathrm{ACH}$ values in multiple zones are generally representative of typical air-exchange rates, even though the concentration within the volume of the house is not perfectly uniform at all times.

Figure 2 shows the measured ACH for each test house during the period of Monday, August 28, until Wednesday, September 6, 2000. The air conditioners operated normally from the beginning of the test until 8:00 a.m. on Sunday, when the return from set-up test began. The ventilation system in the pilot home operated normally until Tuesday morning at 9:00 a.m., at which time the ventilation system was disabled by disconnecting the AirCycler and taping over the outside air intake. Exhaust ventilation systems in both houses were activated on Thursday morning (utility room in the pilot home, master bath in the base-case home). The ventilation systems were again turned off on Friday morning. On Saturday morning, heaters were operated in both homes to evaluate the capacity of the air-conditioning equipment. The return from set-up test began Sunday morning. On Monday morning, both houses returned to normal operation with their primary ventilation systems enabled. The air infiltration tests ended for the base-case house on Tuesday morning, but the pilot home was operated until Wednesday with the outside air duct open and the AirCycler disabled to evaluate the effect of the ventilation fan.

Both houses were very tight when the ventilation systems were disabled, with air-exchange rates ranging between $0.05 \mathrm{ACH}$ at night and $0.15 \mathrm{ACH}$ during the afternoon. These measurements were consistent with estimates based on the blower door tests. In general, the supply ventilation system in the pilot home raised the average air-change rate to nearly $0.35 \mathrm{ACH}$, the level recommended in ASHRAE Standard 62. It appeared that the AirCycler-controlled ventilation fan met the design intent of the system. The air-exchange rate dropped significantly when the ventilation fan was turned off while the outside air duct was left open, especially at night when the air handler operated less frequently. However, the air-exchange rate only increased by about $0.05 \mathrm{ACH}$ for the base case when the master bathroom exhaust ventilation fan was turned on. The increase in air-exchange rate was even smaller in the pilot home when the exhaust fan in the laundry room was used to provide ventilation. The primary reason for the observed ineffectiveness of the exhaust ventilation systems in both houses seems to be undersized exhaust fans.

The air-exchange rate of the prototype was lower during this test than it had been during the earlier test in January 2000 when the average air-change rate during coheating was about 0.17 $\mathrm{ACH}$. Possible explanations include larger stack effect during the colder months, higher average wind speeds, and leakage through the combustion air duct in the utility closet, which did not yet have a door during the earlier test. 


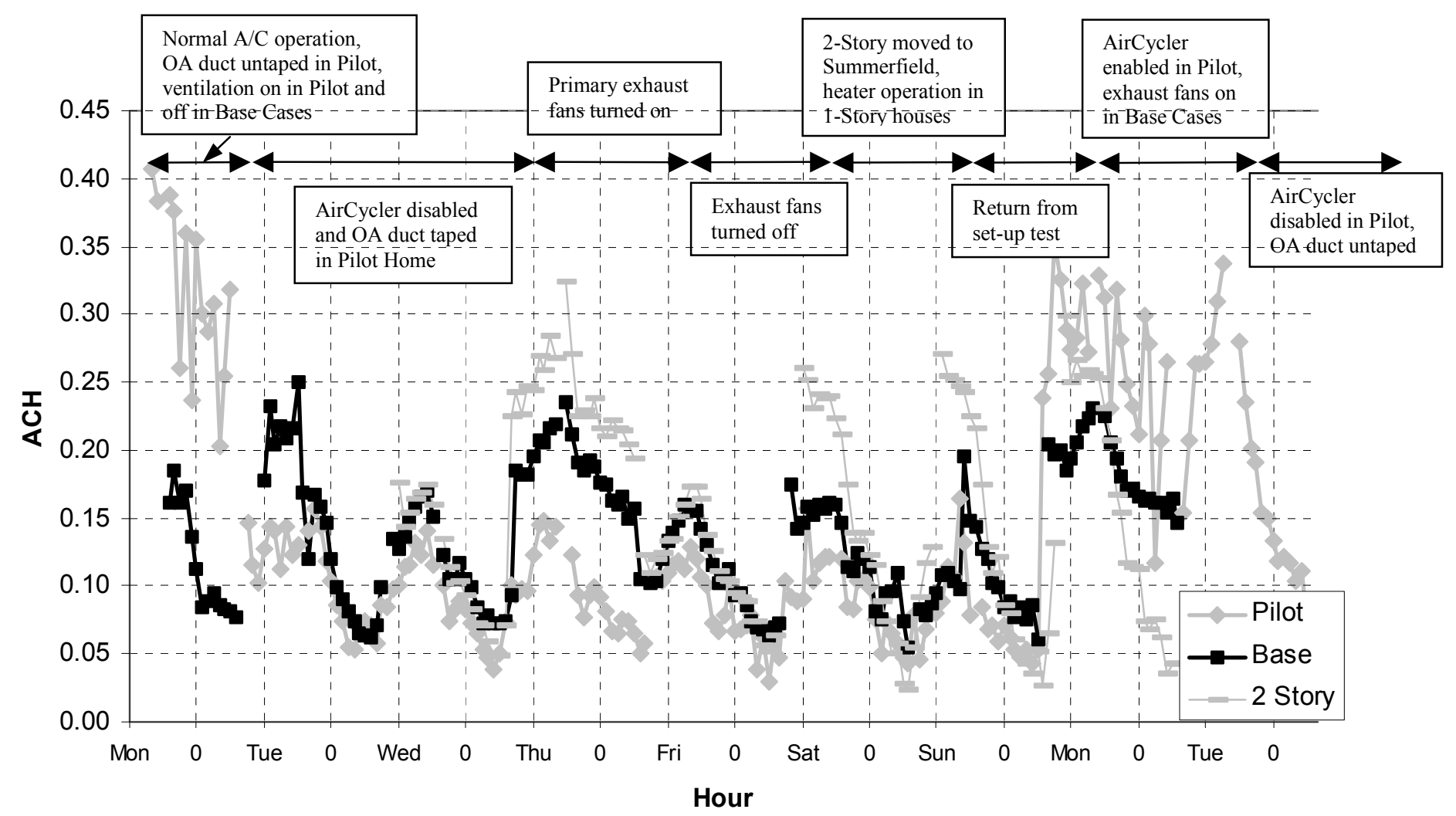

Figure 2. Measured air-exchange rates for prototypes and standard practice houses. (Zero is midnight; day of week label is noon.) The figure includes the results for a two-story home not discussed in this report.

Figures 3 and 4 show the wind speed and inside and outside temperatures during the tracer gas test period. The wind speed was very low throughout the test period, although it was not measured during the first day of testing. The inside-outside temperature difference ranged between 0 degrees at night and almost $20^{\circ} \mathrm{C}\left(68^{\circ} \mathrm{F}\right)$ during the hottest afternoon. Air infiltration showed a tendency to increase with wind speed and temperature difference, peaking in the afternoon, but this also was the time when peak usage of the air conditioners occurred. Average interior temperature was well controlled in both homes, except for a couple of mild excursions in the base case and during the return from set-up test on Sunday night. 


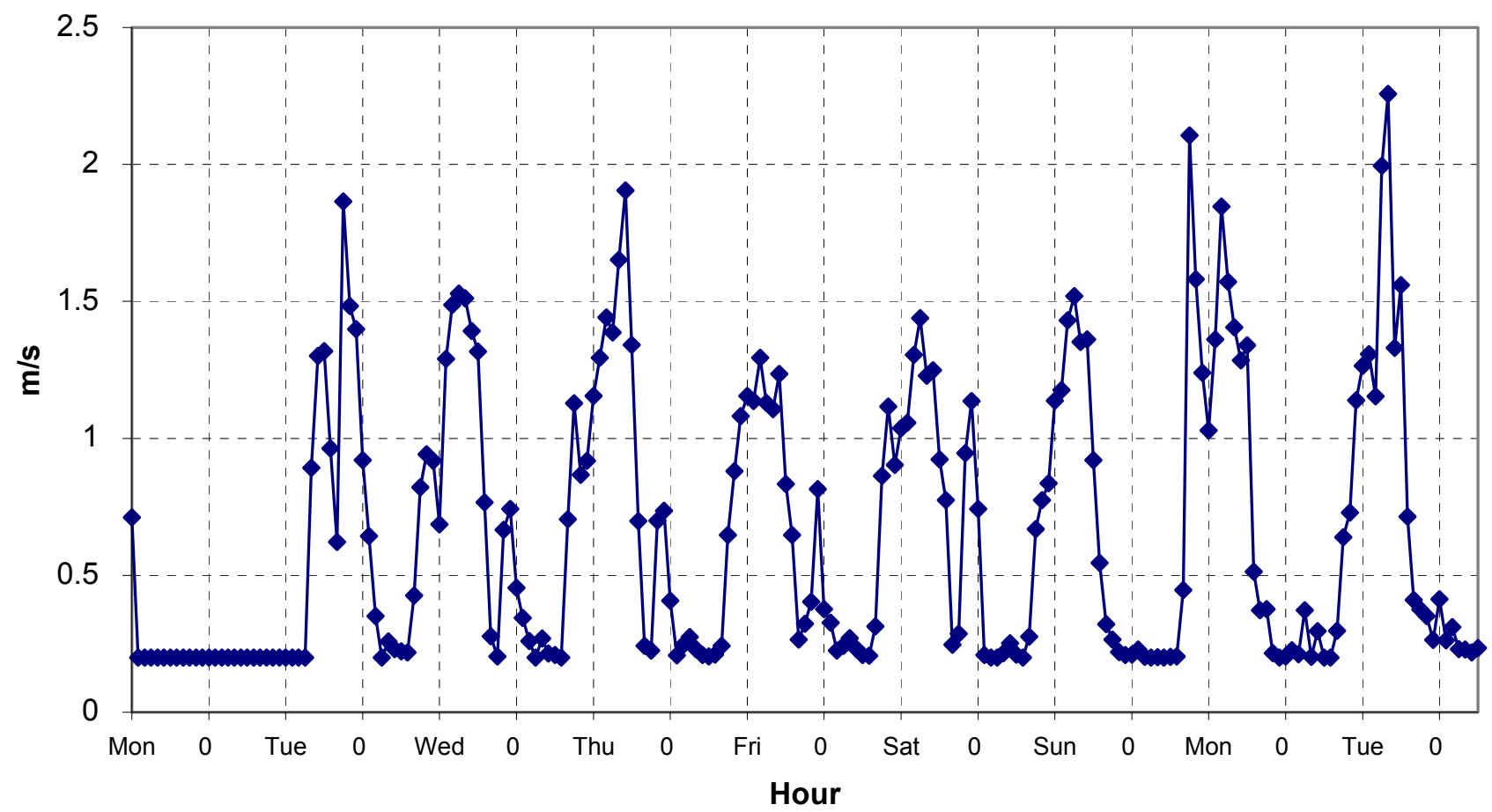

Figure 3. Measured wind speed during the tracer gas measurement period

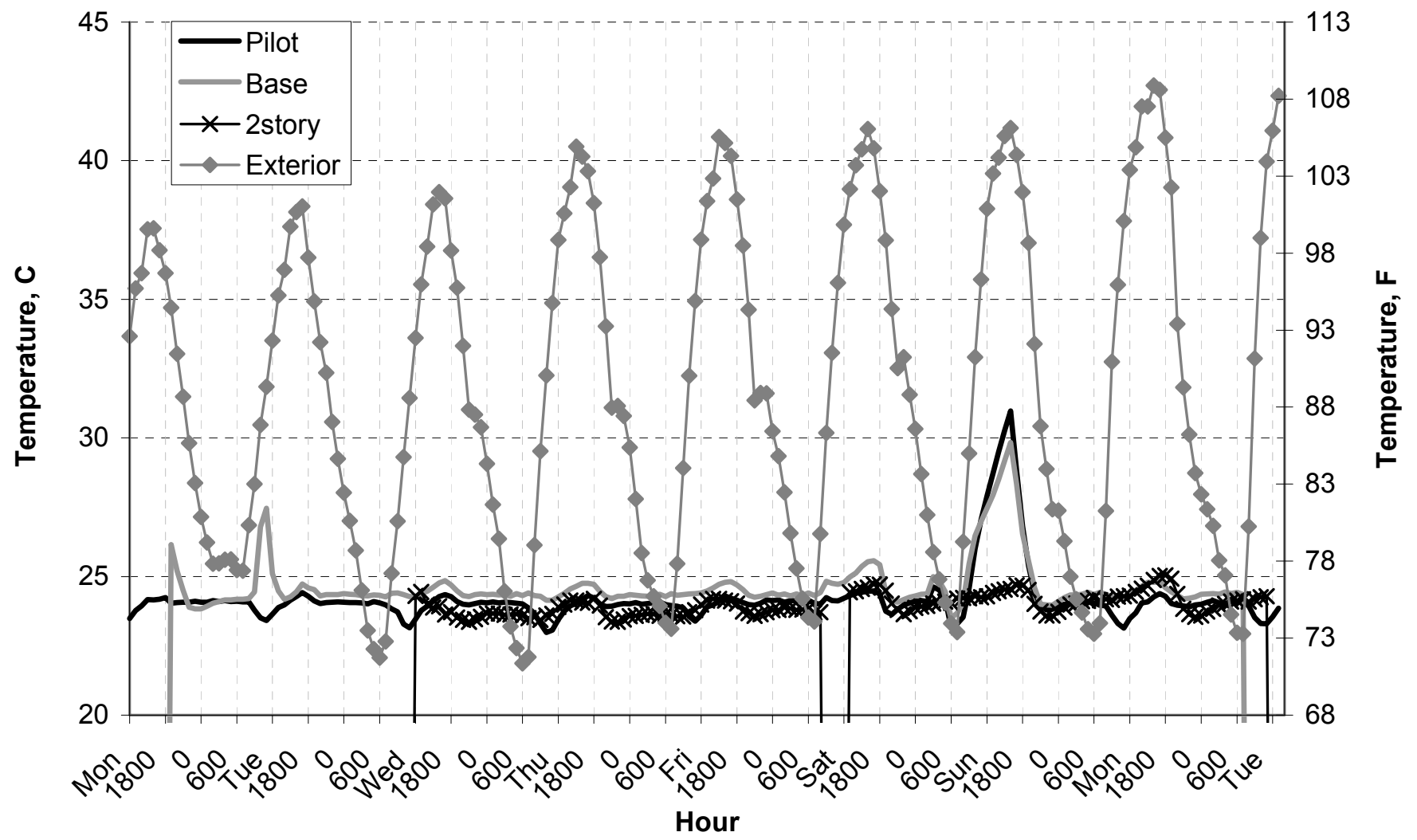

Figure 4. Average air temperatures during the tracer gas measurement period 


\subsection{Field Test Conclusions}

The following observations based on the preceding test results are noteworthy:

- Both test houses had very tight building envelopes

- Several exhaust fans did not provide adequate airflow, including the primary ventilation fan in the one-story base case

- Duct leakage to the outside was significantly smaller in the pilot home, most likely a result of locating the air handler and supply ducts inside the conditioned envelope

- The supply ventilation system in the pilot house raised the air-exchange rate more effectively than the exhaust fans in the base-case houses, none of which exceeded 0.35 $\mathrm{ACH}$ at any point during the test period. 


\section{References}

1. The Energy Conservatory. Minneapolis Blower Door Operation Manual. Minneapolis, Minnesota: The Energy Conservatory, January 2001. (See www.energyconservatory.com).

2. American Society for Testing and Materials. ASTM E779, Standard Test Method for Determining Leakage Rate by Fan Pressurization. West Conshohocken, Pennsylvania: American Society for Testing and Materials, 1992.

3. . ASTM E1827, Standard Test Methods for Determining Airtightness of Buildings Using an Orifice Blower Door Test Method. West Conshohocken, Pennsylvania: American Society for Testing and Materials, 1996.

4. American Society of Heating, Refrigerating, and Air Conditioning Engineers. ANSI/ASHRAE 136, A Method of Determining Air Change Rates in Detached Dwellings. Atlanta, Georgia: American Society of Heating, Refrigerating, and Air Conditioning Engineers, 1993.

5. . ANSI/ASHRAE 119, Air Leakage Performance for Detached Single-Family Residential Buildings. Atlanta, Georgia: American Society of Heating, Refrigerating, and Air Conditioning Engineers, 1994.

6. Judkoff, R. A Computer Program to Calculate Effective Leakage Area from Blower Door Data, and to Calculate Natural Infiltration Rate as a Function of Building and Weather Specific Variables, Solar Energy Research Institute (now the National Renewable Energy Laboratory), November 1986.

7. The Energy Conservatory. TECTITE Version 2. Minneapolis, Minnesota: The Energy Conservatory, 1999. (See www.energyconservatory.com).

8. Sherman, M. and Modera, M. ASTM STP904, Comparison of Measured and Predicted Infiltration using the LBL Infiltration Model, West Conshohocken, Pennsylvania: American Society for Testing and Materials, April 1984.

9. Minneapolis Duct Blaster Operation Manual. $8^{\text {th }}$ edition. Minneapolis, Minnesota: The Energy Conservatory, April 1996. (See www.energyconservatory.com).

10. American Society for Testing and Materials. ASTM E1554, Standard Test Methods for Determining External Air Leakage of Air Distribution Systems by Fan Pressurization. West Conshohocken, Pennsylvania: American Society for Testing and Materials, 1994.

11. Francisco, P.W., and Palmiter, L.S. The Nulling Test: A New Measurement Technique for Estimating Duct Leakage in Residential Homes. ASHRAE Transactions, V. 107, Pt. 1, 2001.

12. ASTM E741, Standard Test Method for Determining Air Change in a Single Zone by Means of a Tracer Gas Dilution. Conshohocken, Pennsylvania: American Society for Testing and Materials, 2000. 
13. Palmiter, L.S., Brown, I.A., and Bond, T.C. Measured Infiltration and Ventilation in 472 All-Electric Homes. ASHRAE Transactions 97(2): 979-987, 1991.

14. Parker, G.B., McSorley, M., and Harris, J. The Northwest Residential Infiltration Survey: A Field Study of Ventilation in New Homes in the Pacific Northwest. ASTM Symposium: Air Change Rate and Airtightness in Buildings. Atlanta, Georgia: April 1989.

15. Sherman, M. H. The Use of Blower Door Data. LBL 35173. Berkeley, California: Lawrence Berkeley Laboratory, March 1998.

16. Liu, M. and Claridge, D.E. Is the Actual Heat Loss Factor Substantially Smaller Than You Calculated? ASHRAE Transactions 101(2): 3 - 13, 1995.

17. Palmiter, L., Brown, I., and Bond, T. Infiltration and Ventilation in New Electrically Heated Homes in the Pacific Northwest. Proceedings of the ACEEE 1990 Summer Study on Energy Efficiency in Buildings, pages 979 - 987. American Council for an EnergyEfficient Economy, 1990.

18. Judkoff, R., Balcomb, J.D., Hancock, C.E., Barker, G., and Subarro, K. Side-by-Side Thermal Tests of Modular Offices: A Validation Study of the STEM Method. National Renewable Energy Laboratory, Golden, Colorado, NREL/TP-550-23940, December 2000.

19. Hendron, B., Farrar-Nagy, S., Anderson, R., Judkoff, R., Hancock, E., and Reeves, P. Building America House Performance Analysis Procedure. National Renewable Energy Laboratory, Golden, Colorado, NREL/TP-550-27754, August 2001. 


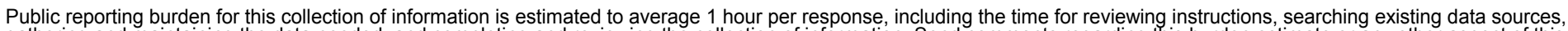

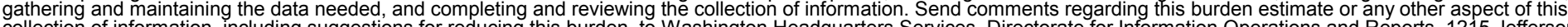

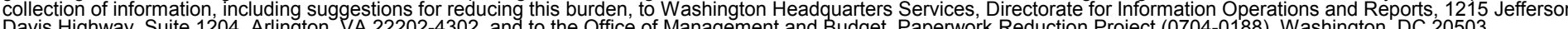

Davis Highway, Suite 1204, Arlington, VA 22202-4302, and to the Office of Management and Budget, Paperwork Reduction Project (0704-0188), Washington, DC 20503.
1. AGENCY USE ONLY (Leave blank)
2. REPORT DATE
August 2002

\section{REPORT TYPE AND DATES COVERED}
Technical Paper

4. TITLE AND SUBTITLE

Building America System Performance Test Practices: Part 2, Air-Exchange

Measurements

5. FUNDING NUMBERS

BET1.8004

6. AUTHOR(S)

E. Hancock, P. Norton, and B. Hendron

7. PERFORMING ORGANIZATION NAME(S) AND ADDRESS(ES)

8. PERFORMING ORGANIZATION REPORT NUMBER

9. SPONSORING/MONITORING AGENCY NAME(S) AND ADDRESS(ES)

National Renewable Energy Laboratory

1617 Cole Blvd.

Golden, CO 80401-3393

10. SPONSORING/MONITORING AGENCY REPORT NUMBER

NREL/TP-550-30270

11. SUPPLEMENTARY NOTES

12a. DISTRIBUTION/AVAILABILITY STATEMENT

National Technical Information Service

12b. DISTRIBUTION CODE

U.S. Department of Commerce

5285 Port Royal Road

Springfield, VA 22161

13. ABSTRACT (Maximum 200 words)

Staff at the National Renewable Energy's Laboratory's Center for Buildings and Thermal Systems and associated contractors perform experiments to quantify the air-exchange characteristics of homes built with the Building America program. This report documents the test practices used. The document was prepared to increase understanding of the advantages and limitations of the approach described. This document is not intended to be a standard protocol for these test measurements.

14. SUBJECT TERMS house testing; blower door; duct blaster; tracer gas; infiltration; duct leakage; ventilation

15. NUMBER OF PAGES

16. PRICE CODE

17. SECURITY CLASSIFICATION OF REPORT Unclassified
18. SECURITY CLASSIFICATION OF THIS PAGE Unclassified
19. SECURITY CLASSIFICATION OF ABSTRACT Unclassified
20. LIMITATION OF ABSTRACT

UL

NSN 7540-01-280-5500

Standard Form 298 (Rev. 2-89) Prescribed by ANSI Std. Z39-18
$298-102$ 